\title{
Raising student's awareness of tsunami hazard in rumah tahfizh bakti ilaahi (RTBI) Bengkulu
}

\author{
Ade S Wahyuni ${ }^{1, *}$, Mukhlis Islam ${ }^{1}$, and Elhusna ${ }^{1}$ \\ ${ }^{1}$ Civil Engineering Department, University of Bengkulu, Jl. WR. Supratman, Kandang Limun, Bengkulu, Indonesia
}

\begin{abstract}
Educating people about disaster risk reduction is part of the responsibility of the local University. Enhancing people's preparedness before disaster strike and how to cope with it, is compulsory and the education need to be done continuously since the natural disaster cannot be predicted. Seismic hazard is quite high in Bengkulu. The RTBI was chosen because of the locations which prone to tsunami hazard and most of the students come from different part of Bengkulu, so the knowledge about tsunami hazard nearby their area is very limited. This paper explains about the process of raising awareness of Tsunami hazard for students in RTBI. Twenty six students were involved in this study. The questionnaire was prepared to study their knowledge about tsunami hazard. The knowledge that they can absorb during the study could be measured by comparing their answer in the questionnaire before and after the study. The result shows, after the study, the students were more aware about the vulnerability of the area and know what to do when the disaster happen.
\end{abstract}

\section{Introduction}

\section{1 disaster risk reduction}

The active subduction between the Indo Australian and Sunda Plates off the west coast of Sumatra produces frequent large earthquake. Along the length of Sumatra, the great Sumatran fault is also capable of producing earthquake up to M7.9, Associated with frequent and large earthquake are the hazards of amplification and liquefaction, tsunami and in mountainous areas, earthquake-induced land sliding [1]. Bengkulu is one of the provinces in Sumatra which is prone to those hazards.

In global scope The Sendai framework for disaster risk reduction 2015-2030 identifies a number of priorities for action in regards to risk reduction. Understanding disaster risk in all its dimensions of vulnerability, capacity, exposure of persons and assets, hazard characteristics and the environment become the first priority [2]. Disaster risk reduction becomes the responsibilities of every single element in the community mostly for the people who live in the area which is prone to any disaster.

The resilient communities need to be prepared in the area which is vulnerable to disaster. If the community knows what to do when disaster happen, the number of victim could be reduced. This is about changing the mindset; try to reduce the impact of hazard before it happens and not focus on the recovery part when the disaster already occurred. Woods [3] mention the 4 R's for preparing the resilient communities who lives in the area vulnerable to disaster. The resilience communities mean:
1. Understand the risk they face and do what they can do to reduce their impacts (Reduction).

2. Ready and prepared to react when an event occurs (Readiness).

3. React and take appropriate action during an emergency (Response).

4. Get back to normal as soon as possible (Recovery).

Grace [4] mentions four steps of Risk focused process to incorporate natural hazard i.e.: Understand the hazard, assess the consequences and likelihood, evaluate the risk and decide how to treat the risk.

\subsection{Tsunami awareness}

Tsunami is a series of long waves generated by large volumes of seawater being rapidly displaced. Tsunami waves flood the coastlines and cause devastation to property, injuries and loss of live [5].

Tsunami countermeasures can be divided into structural and non structural. Structural countermeasures involves: tsunami Shelter, Tsunami Barrier (Sea Wall, Vegetation, Distance), Escape roads (Wide enough, traffic management). The non structural countermeasures include: increase awareness, Early warning system, Readiness [6].

When tsunami height is so big and beyond the selected design criteria, structural countermeasures may fail such as sea walls are overtopped and vertical shelters are inundated or even drawn [7]. However, the sea walls, to some extent, delivered protection to some level and reduce the casualties. Reinforced concrete buildings are

\footnotetext{
* Corresponding author: ade.sri.w@unib.ac.id
} 
more tsunami resistive than masonry and wooden buildings (Shuto, 1990 in Leonard et al 2011) [8].

Power [9] explains the approach in modeling the tsunami in The New Zealand Probabilistic Tsunami Hazard Model (NZPTHM) that introduced 4 levels of evacuation zoning:

a. Level 1 bathtub

The tsunami is assumed to maintain the height as it propagates inland as it possesses at the coast.

b. Level 2 Rule based

This approach depends on rules to relate the height that a tsunami can potentially reach (Leonard et al 2009)

c. Level 3 Model Scenarios for a given return period This approach based on the selected scenarios is the representative of the largest tsunami within a given return period.

d. Level 4 Inundation modeling for all relevant events This is the ideal approach, in which all possible events are modeled hydrodinamically through to inundation

Furthermore vertical evacuation is introduced as an alternative means of evacuation in situations where the distance involved in reaching high ground are too large to be reached in the time available. Care needs to be taken to ensure that any vertical evacuation structure is strong enough to withstand all plausible tsunami and has sufficient capacity to safely hold the number of people hoping to use it [9].

The resilience communities will be able to manage their own hazard and risk. The socialization of the 4 R's (Reduction, Readiness, Response, and Recovery) is one way to build the resilience community. Bengkulu University as local state university has three pillars i.e. education, research and community service. Those three pillars become mandatory to be done for every academic member. Socializing about tsunami hazard, how to evacuate, where to evacuate, are part of the community service program.

This paper introduces about how to response to strongly felt earthquake, that is potential to come with tsunami, preparing the getaway item ready for immediate evacuation, identifying the construction building for vertical evacuation to the students of RTBI. The tsunami tank was also introduced as the interactive learning media.

\section{Problems}

RTBI is a boarding school for boys who want to focus on memorizing Qur'an. There are 26 students stay here with the age ranging from 13-16 years old. This RTBI is located in Belato Street no 56, Bengkulu.

Fig 1. shows the location of RTBI in the map. It is quite close to the beach. The Google earth suggested that the distance of RTBI from the coastline is about $300 \mathrm{~m}$. This is one reason why we chose the place for socializing the tsunami, to speak with the student about tsunami risk and evacuation plan.

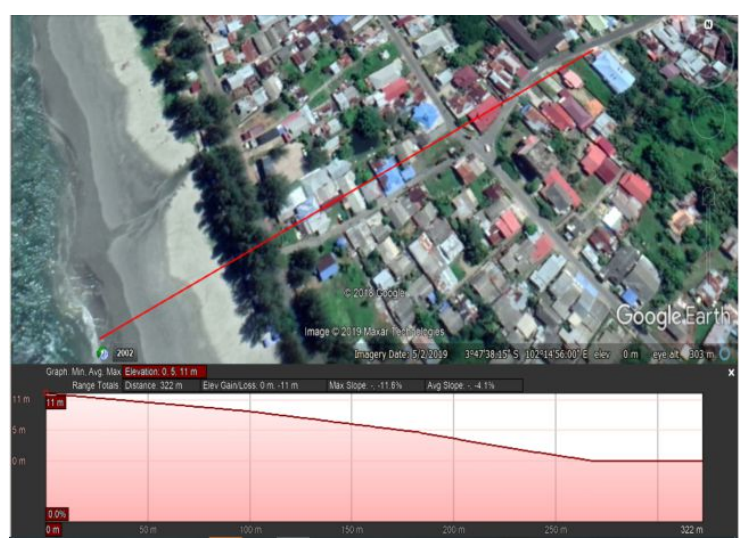

Fig 1. The location of RTBI

Another reason is the origin of the students. All of the students who are memorizing Qur'an in this RTBI come from different places of Bengkulu, North Bengkulu, South Bengkulu, Kaur, and Bengkulu city itself. Some students come from Rejang Lebong, Curup which is mountainous area and quite far from the beach.

\section{Methods}

The methods use in sosializing the 4R ( Reduction, Readyness, Response, Recovery) in RTBI involves:

1. Socializing the knowledge about earthquake and tsunami

a.Watching video about the devastating tsunami which happen all over the world

b. Explainig about the fact about tsunami

c.Interactive activity with tsunami tank

2. Introducing the prepared bag to the students

a. Explaining why do we need a prepared bag in case of emergency

b. What should be inside the prepared bag

c. Evaluation with guessing game of what inside the bag

3. Introducing the possible vertical evacuation nearby the RTBI.

The survey was conducted by giving questionnaire to gain their knowledge, how good is their knowledge about tsunami. The questionnaire was adopted from the StIRRRD's Community project in Seluma, Bengkulu. The aim of StIRRRD (Strengthen Indonesian Resilience in reducing Risk of Disaster) is Reducing Risk of Disaster in Indonesia in Collaboration of University of Gajah Mada and GNS Science New Zealand and funded by Ministry of Foreign Affair and Trade (MFAT) New Zealand. Ten Districts from 4 provinces which are prone to disaster became part of this project namely, Palu, Donggala, Morowali, Padang, Agam, Pesisir Selatan, Bengkulu, Seluma, Mataram, and Sumbawa. Bengkulu University as well as 3 more universities (Andalas University, Tadulako University and Mataram University also involved in this activity.(Fathani, et al 2017)[10].

Sixteen questions in the questionnaire were given to every student twice, so their answer can be compared. The questions were divided into three section namely: 1) risk perception in current location 2) Tsunami preparedness 
and 3) Potential tsunami scenarios. The question in the questionnaire is tabulated in Table 1. This strategy could measure how good they can absorb the explanation given by the community service team. Fig. 2 shows the students are answering the question in the questionnaire.

Table 1. The questionnaire

\begin{tabular}{|c|c|}
\hline \multirow[t]{2}{*}{1} & Risk perception at current location \\
\hline & $\begin{array}{l}\text {-How long have you lived in this community } \\
\text {-Is your house in a tsunami evacuation/hazard zone } \\
\text {-How often do you think about tsunami (Never, once a } \\
\text { year, once a month, once the week, everyday) } \\
\text {-have you received any information regarding preparing } \\
\text { for tsunami from friend, neighbour, relative, } \\
\text { governmentnt, local university, NGO } \\
\text {-How do you expect to be warned that a tsunami is } \\
\text { coming within the nexthour (text message, TV, Radio, } \\
\text { door to door, warning sirens) } \\
\text {-Have you seen any tsunami hazard zone maps for this } \\
\text { community } \\
\text { - Are there official tsunami evacuation routes for this } \\
\text { community } \\
\text { - Do you know of any locations which might generate a } \\
\text { tsunami that could affect your community } \\
\text { - If you felt a strong earthquake while at the beach, how } \\
\text { much time will you have to move to safety from any } \\
\text { approaching tsunami it may cause }\end{array}$ \\
\hline \multirow[t]{2}{*}{2} & Tsunami Preparedness \\
\hline & $\begin{array}{l}\text { - Do you think that you and your household are prepared } \\
\text { enough to deal with tsunami } \\
\text { - Do you have a 'getaway kit' or items ready in case you } \\
\text { need to evacuate your home quickly } \\
\text { - What is in that kit / what are those items } \\
\text { - Do you have a specific destination in mind if you had } \\
\text { to evacuate after a tsunami warning } \\
\text { - How long do you expect to be evacuated for after a } \\
\text { tsunami hits the coast? }\end{array}$ \\
\hline \multirow[t]{2}{*}{3} & Potential tsunami scenarios \\
\hline & $\begin{array}{l}\text { Imagine a severe earthquake occurs (lasting longer than } \\
\text { a minute or during which it is hard to stand), at } 11 \mathrm{am} \\
\text { (scenario A), or } 11 \mathrm{pm} \text { (scenario B) on a weekday. } \\
\text { Imagine you have not heard any official tsunami } \\
\text { warning } \\
\text { - What would you do? } \\
\text { - Would you evacuate } \\
\text { - If not, what are your reasons for not evacuating } \\
\text { If you decided to evacuate(Please answer the following } \\
\text { questions even if you do not think evacuation is needed) } \\
\text { - What would you do before evacuating } \\
\text { - About how long would all of this take? } \\
\text { - Where would you evacuate to? } \\
\text { - How would you travel to your destination? }\end{array}$ \\
\hline
\end{tabular}

The movie about tsunami which happens all over the world, were shown to the students. Tsunami could destroy the whole city in a very short period of time and take everything on its way, manmade buildings, trees, and people. This catastrophe could take thousands of lives and millions of loss. Fig 3 shows the students pay attention on the video about tsunami

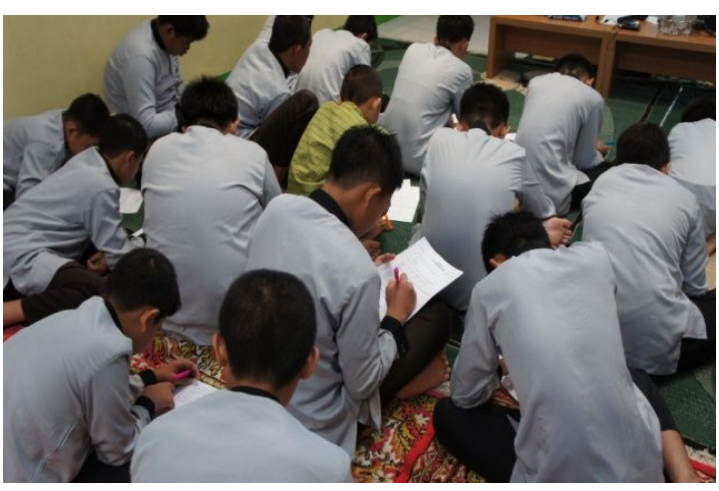

Fig 2. The students are filling up the questionnaire

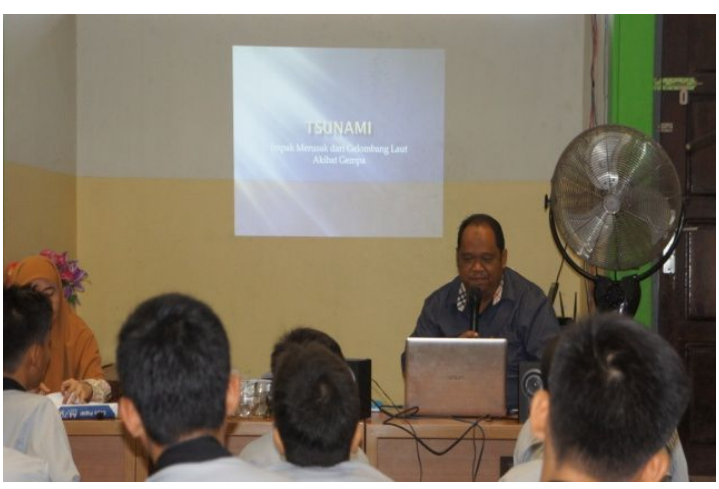

Fig 3.explanation about tsunami

Some facts about tsunami were explained to the students such as:

a. Tsunami waves can be very long, as much as 100 kilometers and be as far as one hour apart. They are able to cross entire oceans without great loss of energy.

b. A tsunami may be less than 30 centimeters in height on the surface of the open ocean, which is why they are not noticed by sailors. But the powerful shock wave of energy travels rapidly through the ocean as fast as a commercial jet. Once a tsunami reaches shallow water near the coast, it is slowed down.

c. The top of the wave moves faster than the bottom, causing the sea to rise dramatically.

d. Witnesses have reported that an approaching tsunami is sometimes preceded by a noticeable fall or rise in the water level

e. The danger from a tsunami can last for several hours after the arrival of the first wave. A tsunami wave train may come as a series of surges that are five minutes to an hour apart. The cycle may be marked by a repeated retreat and advance of the ocean.

The tsunami could not be stopped, but the number of victim and the loss could be reduced by building the resilience community that could manage their own hazard and risk. Dealing with the teenage students sometimes is not easy. They normally will get bored easily if we use the one way communication where they just listen to explanation. It will be more powerful if they involve in the activity. The tsunami tank is introduced to see what happen when tsunami hit the land with a few model houses. The students already watched the video of the 
tsunami and already understand that The tsunami forms after a big earthquake that make a sudden displacement of the ocean floor. Tsunami is like a tide, the tide goes out before it comes in. As the tsunami approaches water is drawn back from the beach to effectively help feed the wave. In the tsunami tank the waves was created by dragging the water back to mimic the real tsunami. Once it relieves, the water will go back to the beach with the bigger wave and higher energy. The students took turn to use the tsunami tank. Creating a wave is quite a challenge. Not every student can do it in the first place but they are keen to try it again and having fun. They are really keen to try try to create the big wave to sweep the little houses in the beach. Fig.4, Fig.5 and Fig. 6 show that this interactive activity works quite well. The students were enjoying the activity of trying to create wave that can sweep the house nearby the beach

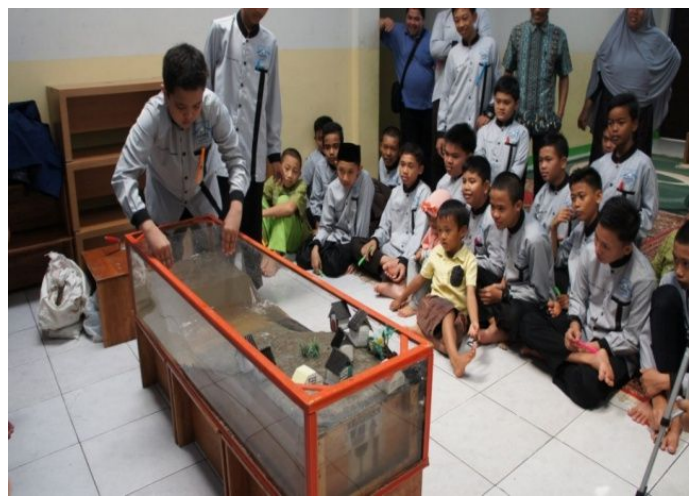

Fig.4. The students focus on the tsunami tank activity

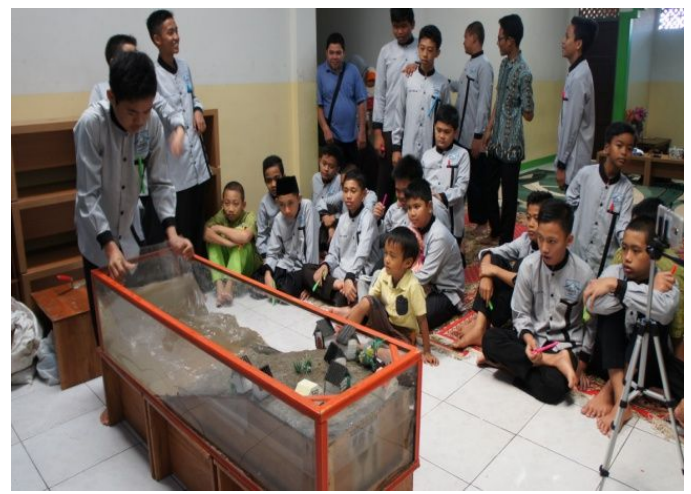

Fig.5 The students take turn to create wave in tsunami tank

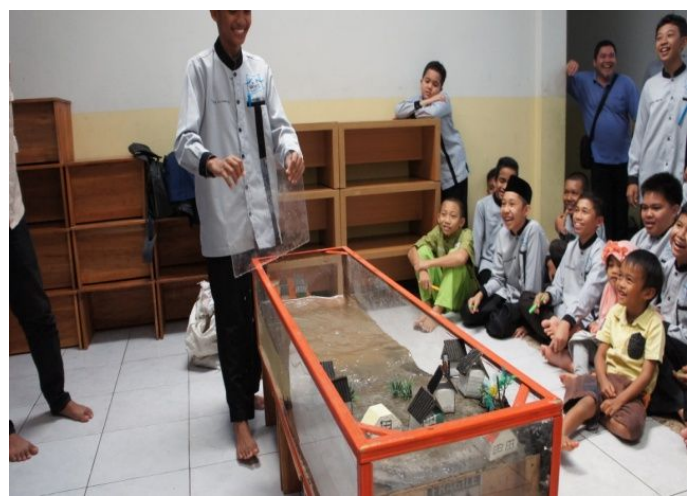

Fig.6 The students are having fun with this tsunami tank
The 'prepared bag' was shown to the students and what should be inside it. This is also part of the lesson in the Tsunami preparedness section. Fig.7 Shows the prepared bag and it's content.

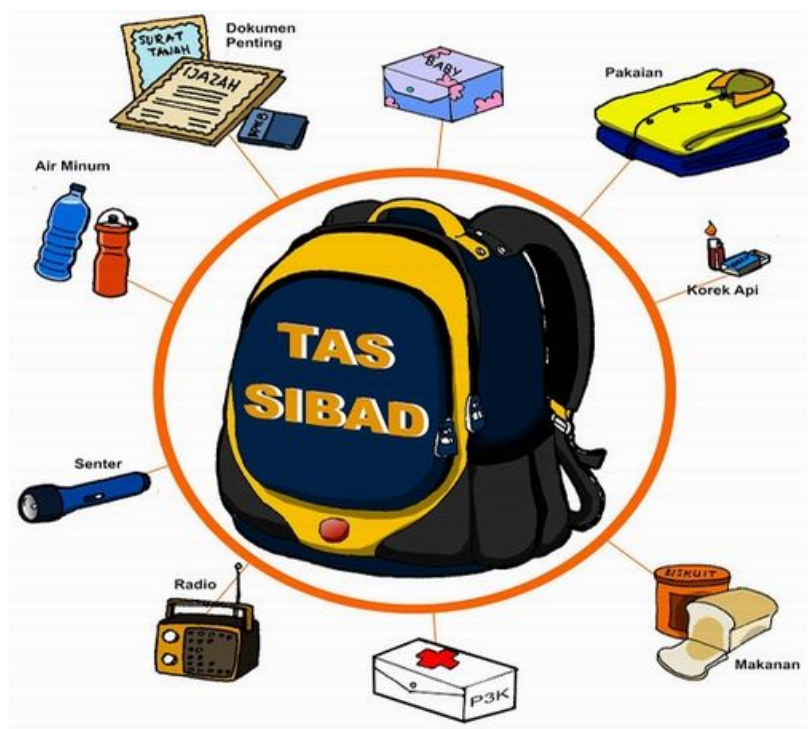

Fig.7. The prepared bag

The contents of the prepared bag are:

1. Important document

2. Food

3. Drink

4. Radio

5. Clothes

6. Toiletries

7. First Aid Kit

8. Torch

9. Candle and Matches

The Food and drink should be checked for the expiry date and the batteries for the radio and torch .

We can measure about how good they can absorb the lesson. All of the students can answer the question of what should be in the prepared bag, after presentation the bag and the item inside one by one. Fig. 8 shows the enthusiastic of the student in answering question about what inside the bag

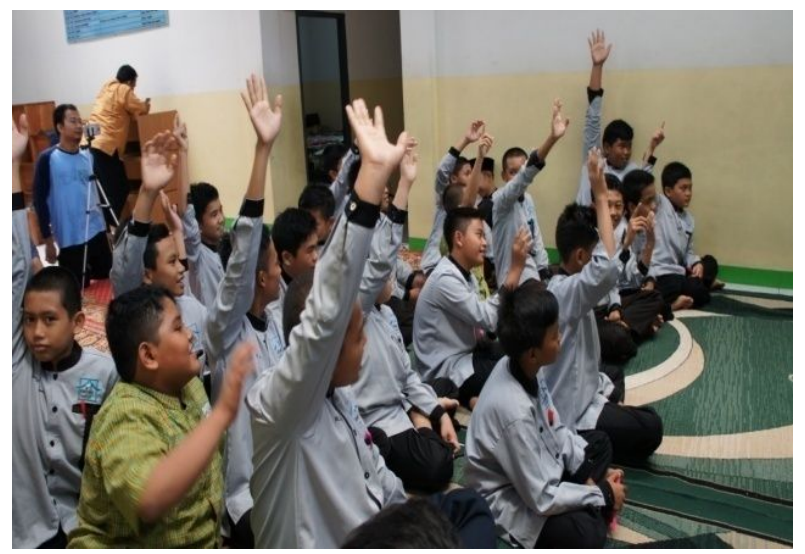

Fig.8 The students answer the question enthusiastically 
The possible vertical evacuation nearby RTBI were also presented to the students. The community service team try to Fig. out where is the best place to evacuate, the vertical evacuation that could be reached within 15 minutes or going further from the beach to the higher ground.

\section{Result and Discussion}

Some of the questions in the questionnaire were adopted from the Community Engagement activity in Seluma, as part of StIRRRD programme in which Bengkulu University also involved [11].

The students were asked to imagine if there is a big earthquake, which is more than 1 minute and make us hard to stand up. The questionnaire were asking what will they do in case of such tsunami occur in two different scenarios. The first scenario is the tsunami occurs at 11 am and the second one is at $11 \mathrm{pm}$.

Their answers are quite interesting about $42 \%$ of the students don't know where to go in case there is tsunami. The students are so innocent with their simple answer. Most of them about $58 \%$ already know that they have to run to save their life to the higher place, when there is a strong big earthquake that might come with tsunami.

However when the students were asked to draw a sketch about where to go, $97 \%$ percent couldn't make it, while another $3 \%$ can draw some picture but not to a specific place.

Some of the student answered that they are going to join their family in Kepahyang (which is hundred kilometers away from their place right now). This means that they already know to move to higher place. What they do not realize that tsunami might come anytime when they might not with their family. If it is holiday, that might be the case, since everybody will go back to their house.

We try to educate them of what to do by introducing the vertical evacuation that could be use to evacuate as temporary shelter to safe their life. This activity were done by dragging the line on Google earth so we can see clearly our location and the nearest, safest place for temporary evacuation. Since Google earth could give the approximate height from the coastline, we can show the students some alternatives to be away from the beach area.

We already discussed with the students that normally the tsunami will come after the big earthquake and the water in the ocean go back to the ocean drastically. The water will comeback with the extra power that will take everything on their way. How the wave moves were demonstrated by the tsunami tank. This interactive activity really drew the students' attention. The students become more understand about the powerful wave and they try it by themselves to create such wave in the tsunami tank that will sweep a few mini houses near by the beach. The demonstration can really show that the powerful wave could drag the houses. The students really enjoy this interactive activity and start to ask some question regarding the tsunami.

Regarding the getaway kit, the students already understand why everybody have to prepare their own bag with importand stuff completed with food, drink and clothing for a few days, so they can survive before the help is coming.

\section{Conclusion}

This study finds that the socialization of tsunami needs to be done continuously to educate the community. Nobody hopes that such disaster will come but when it comes, they know what to do to reduce the number of victim and loss.

Building the resilient community through the 4 R's (Reduction, Readiness, Response, and Recovery) is a long term program and mandatory in the vulnerable area. This should be done by continuously socialize to the community about the disaster that might happen any time. It doesn't mean that they have to relocate to other places because there is no guarantee that they will not find any hazard in new location.

\section{References}

1. P. Upton, Earthquake Hazards along the Western edge of Sumatra. Proc. workshop DRR StIRRRD (2015).

2. M.J. Goldsmith, Methods to Understand and Reduce the Risk Associated with Natural Hazards, Otago, New Zealand, Proc. StIRRRD NZ comparative study programme (2016).

3. R. Woods, Disaster Risk Reduction Coordination in New Zealand, Proc. DRR seminar (2017).

4. E.S. Grace Incorporating Natural Hazards into development plans in new Zealand, Proc. StIRRRD NZ comparative study programme (2016).

5. E. Hunt, Tsunami evacuation plan Orewa, Proc. StIRRRD NZ comparative study programme (2016).

6. Wisyanto, W. Mahardi, T. Alvisyahrin, Juriono. Tsunami countermeasures: An action plan for Indonesia. Presentation paper of ICHARM/PWRI Training. Tsukuba (2008).

7. J. Tucker, The Failure of Kamaishi Tsunami Protection Breakwater, J of Undergrad Eng Research and Scholarship. Canada, (2013).

8. G.S. Leonard, G. Prasetya, L. Pearse, S. Fraser, N. Evans, W.S.A. Saunders, D. Monastra, Scoping study for evaluating the Tsunami vulnerability of New Zealand Buildings for Use as Evacuation Structures, GNS Science Report (2011).

9. W.L. Power, Tsunami Hazard Modelling in New Zealand. Proc StiRRRD NZ Comparative Study Programme (2016).

10. T.F. Fathani, W.Wilopo, M. Daly, P. Glassey, Penguatan Ketangguhan Indonesia Melalui Pengurangan Risiko Bencana (STIRRRD). Proc Seminar Nasional Pengurangan Risiko Bencana 2017

11. P. Glassey, Initating Tsunami Awareness community Engagement, Rawa Indah Seluma, https://stirrrd.org/category/seluma (2018). 